\title{
Comparing the Calculations of Energy Consumption and Greenhouse Gases Emissions of Passenger Transport Service
}

\author{
Martina Hlatká \\ Institute of Technology and Business in \\ České Budějovice \\ Faculty of Technology \\ Department of Transport and Logistics \\ Czech Republic \\ e-mail: hlatka@mail.vstecb.cz
}

\author{
Ladislav Bartuška \\ Institute of Technology and Business in \\ České Budějovice \\ Faculty of Technology \\ Department of Transport and Logistics \\ Czech Republic \\ e-mail: bartuska@mail.vstecb.cz
}

\author{
DOI 10.17818/NM/2018/4SI.11 \\ UDK 656.025.2 \\ $502 / 504$ \\ Original scientific paper \\ Paper accepted: 28. 8. 2018
}

\section{Summary}

The paper, within the model example, deals with the calculation of energy consumption in transport and with the calculation of greenhouse gas emissions generated by transport according to the methodology given in EN 16258 of 2013. The model example shows the passenger transport between point $A$ and point $B$ within bus transport and alternatively using the air transport combined with bus transport.

\section{KEY WORDS}

greenhouse gas emissions energy consumption EN 16258 methodology transport

\section{INTRODUCTION}

Transport is an important part of the logistics chain. On the one hand, there is a constantly increasing demand for these services; on the other hand, transport is a big polluter of the environment. In connection with the development of transport services, in the 1990's negative impacts of transport on the environment started to emerge. At the beginning, it was mainly noise, vibrations, land-grabbing related to the operation of transport services. Over time, other negative factors that affect the environment started to emerge. They are called greenhouse gases and include carbon dioxide $\left(\mathrm{CO}_{2}\right)$, methane $(\mathrm{CH} 4)$, nitrous oxide (NzO), hydrofluorocarbons (HFCs), perfluorocarbons (PFCs) and sulphur hexafluoride (SF6). The most widespread greenhouse gas is carbon dioxide. Recently, a wide range of governmental and non-governmental organizations have started to deal with reducing these negative impacts. Gradually, plans to reduce these negative impacts at the level of towns, regions, states and the EU started to be developed. This issue is in the spotlight, despite the fact that currently the amount of greenhouse gases released to atmosphere is decreasing. Still, the emissions need to be reduced. Appropriate measures include emission allowances, restrictive or incentive solutions.

The main objective of all world policies is reducing negative impacts of transport as well as all human activities on the environment. Finding a solution to this problem is not easy. Finding solution would mean to re-examine the existing life priorities and also to consider whether it is really necessary to live in abundance to the expense of future generations. It is necessary to see the environment as a form of heritage to pass to future generations the same way as our generation inherited the environment. If we want the concept of sustainable development to be in line with economic and social progress, an effective solution to achieve it has to be found.

\section{EXHAUST GAS EMISSIONS FROM COMBUSTION ENGINES}

Pollutants spread partly in the air and their influence can be seen in the wider environment than at the place of their occurrence. To analyse such negative effect it is necessary to understand the relationship "emission - transmission - deposition - immission" [1].

Emission - is a term related to the formation and releasing of pollutants. Emissions are expressed in absolute terms, such as weight of a specific pollutant for air pollutants or pollutants generated by one vehicle per a distance travelled, that is, in relation to distance.

Transmission - this term describes spread of pollutants in the air. Transmission depends on a number of factors, such as air temperature and humidity or wind speed and direction.

Deposition - it is a term describing deposition of pollutants changing the site due to transmission on the Earth surface. Wet deposition includes precipitations in a liquid form, e.g. rain, fog, etc. Dry deposition includes pollutants that, due to transmission, fall from the atmosphere in the form of dust.

Immission - this term describes the concentration of pollutants in the air and their impact on people,environment, and buildings. The extent of the impact depends on the concentration of the pollutant at the place and time of their activity. Immissions are expressed in absolute units of mass per volume, e.g. $\mathrm{g} / \mathrm{m} 3$.

If the impact of specific pollutants is described, it is necessary to analyse the complex way from emissions to immissions, as it is the only way possible to identify the effect and place of their activity, that is, according to the relation cause - effect [2].

Exhaust gases generated by combustion of fuel in engine cylinders are divided into the following groups [2]:

Carbon monoxide (CO) - it is poisonous for human organism, disables the transfer of oxygen to lungs. It arises by 
incomplete oxidation of carbon contained in hydrocarbon fuel. The primary cause of its formation is the lack of oxygen in the mixture combusted.

Nitrogen oxides (NOx) - Harmful effects on human organism are relatively low. However, in case of its presence in the atmosphere, its OXIDATION INTO nitrogen dioxide occurs, which is classified as more harmful. NOx depends on the combustion temperature and richness of the mixture combusted.

- Unburned hydrocarbons $(\mathrm{CHx})$ - they are very hazardous and carcinogenic substances. They arise during abnormal combustion on cooler walls of engine cylinders, or during cut out - failure of combustion of mixture in engine.

- Sulphur oxides (SO2) - this substance is generated mainly by diesel engines and depends on the sulphur content in diesel oil. It gradually decreases along with the trend of sulphur decrease in diesel oil.

- Particulate matter (PM) - are generated only in diesel engines. They contain primary carbon, organic carbon, sulfate, nitrogen and water. Chronic exposures cause histopathologic changes mainly to the lungs. PMs are generated by combusting unvaporized droplets of fuel in high temperature environment. PM emissions are thus related to the quality of fuel spraying in the cylinder.

\section{GREENHOUSE GASES EMISSIONS}

The Kyoto protocol identifies six FUNDAMENTAL gases that have major impact on climat changes in the Earth. It is carbon dioxide (CO2), methane (CH4), nitrous oxide (N2O), sulphur hexafluoride (SF6), hydrofluorocarbons (HFCs) and perfluorocarbons (PFCs). The first three gases mentioned are directly related to combusting fossil fuels in freight transport. HFCs and PFCs are most frequently generated in the air-conditioning equipment, while SF6 are generated in industrial production of semiconductors [3].

The Kyoto protocol further states that these greenhouse gases must be converted into aggregated average emissions in the units of carbon dioxide equivalent (CO2e). This conversion takes into account different ability of gases to cause greenhouse effect and different lifetime in the atmosphere. Although $\mathrm{CO} 2$ does not have the ability to cause greenhouse effect, it is still the most important anthropogenic greenhouse gas. That is the reason why other gases are converted into $\mathrm{CO} 2$ [4].

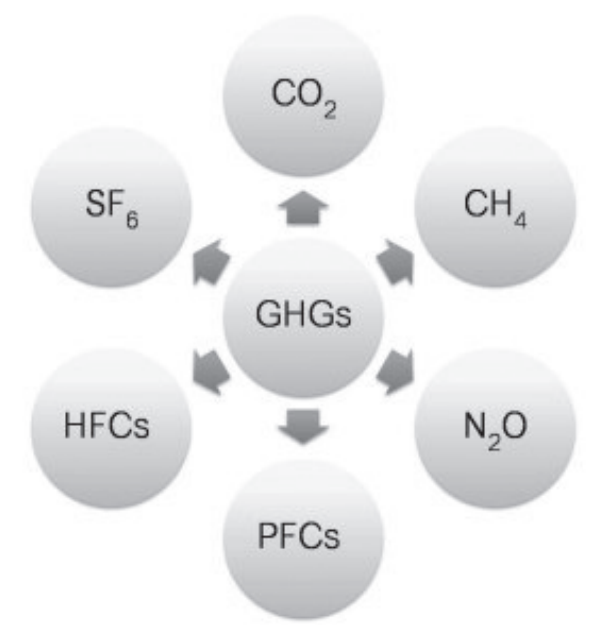

Source: [5]

Figure 1 Greenhouse gases scheme

\subsection{Methodology for calculation of energy consumption and greenhouse gases emissions of transport services according to en 16258 (2013)}

The EN 16258 (2013) standard sets out a methodology and requirements for calculation and declaration of energy consumption and greenhouse gases emissions of transport services. The Standard was created to unify the processes of calculating carbon footprint processes issued for the purpose of their comparison. When calculating the energy consumption and emissions related to the means of transport, it is necessary to take into account also the energy consumption and emissions related to the energetic processes for production and distribution of fuels or electric energy. This ensures that the standard takes "well-to-wheel" (WtW) in calculation and declaration. WtW approach is based on monitoring the energy consumption and emission generation from the energy production to its final consumption. This approach includes two parts: energy consumption and emission generation in production of fuels or electric energy Well-to-Tank (WtT) and energy consumption and emission of greenhouse gases related to the operation of a vehicle Tank-to-Wheels (TtW) [6].

Well-to-Wheels analysis thus establishes the consumption of fossil energy and production of $\mathrm{CO} 2$ equivalent for driving conditions corresponding to the European homologation cycle. This method does not use direct measurement on vehicles, but uses ADVISOR, a software simulator of driving cycle developed by the National Renewable Energy Laboratory. The objective of the simulator is to accelerate and facilitate the tests of motor vehicles. The ADVISOR program enables to determine the emissions production for different vehicles and thus evaluates the potential contribution of hybrids to reducing the greenhouse gases emissions [7].

The Standard further specifies the individual processes and principles essential for the proper calculation of energy consumption and greenhouse gases emissions.

Operational processes of vehicle must include the operation of all vehicle systems including the propulsion and additional services. This means that it must include main engines, auxiliary equipment used for maintaining the temperature of the load area and vehicle handling or transshipment systems.

The principles of calculating energy consumption and greenhouse gases emissions of transport services must take into consideration all vehicles used for operating transport services, including those that are subcontracted. Furthermore, also the total energy consumption from each energy carrier and all runs, both loaded and empty runs [6].

The calculation per one transport service must match exactly the following steps:

- Identification of various sections of transport service.

- Calculation of energy consumption and greenhouse gases emission for each section.

- Sum of the results for each section.

The calculation of the total energy consumption and greenhouse gases emissions is carried out according to the following formula:

Well-to-wheels pro energy consumption VOS:

$$
E_{w}(V O S)=F(V O S)^{*} e_{w}
$$

Well-to-wheels for greenhouse gases emissions VOS:

$$
G_{w}(V O S)=F(V O S)^{*} g_{w}
$$


Tank-to-wheels for energy consumption VOS

$$
E_{t}(V O S)=F(V O S)^{*} e_{t}
$$

Tank-to-wheels for greenhouse gases emissions VOS

$$
G_{t}(V O S)=F(V O S)^{*} g_{t}
$$

)

Where:

- $\quad F(V O S)$ is a total fuel consumption used for VOS (e. g. F (VOS)

is five thousand liters of diesel)

- $\quad$ ew is well-to-wheels energetic factor for fuel consumed (e.g. for diesel, ew $=42.7 \mathrm{MJ} / \mathrm{l}$ ).

- gw is well-to-wheels emissions factor of greenhouse gases for fuel consumed (e.g. for diesel, gw = 3.24kgCO2e/l).

- $\quad$ et is tank-to-wheels energetic factor for fuel consumed (e.g. for diesel, et = 35.9MJ/I).

- gt is tank-to-wheels emissions factor of greenhouse gases for fuel consumed (e.g. for diesel, gt $=2.67 \mathrm{kgCO} 2 \mathrm{e} / \mathrm{l}$ ).

The values for energetic factor and factor of greenhouse gases emissions must be in line with the attachment A of this Standard. The density and energy factor of fuels is showed in Table 1 [6].

In case that the realized transport service consists of more sections (e.g. different customers, different numbers of passengers transported, distance travelled by a loaded and empty vehicle), it is necessary to implement the calculation of energy consumption and emissions to a specific section. The procedure in this case is as follows:

- VOS used for the realization of transportation services in the relevant section is identified.

The whole VOS is quantified.

- The overall VOS consumption of energy and emissions is calculated according to (1), (2), (3) and (4).

- The share of energy consumption and emissions for the given section of transport service is calculated as a ratio of performance attributable to the section of transport service and performance of the system of vehicle operation.

The calculations are carried out as follows:

$$
\begin{gathered}
S(\text { leg })=T(\text { leg }) / T(\text { VOS }) \\
E_{w}(\text { leg })=E_{w}(\text { VOS }) * S(\text { leg }) \\
G_{w}(\text { leg })=G_{w}(\text { VOS }) * S(\text { leg })
\end{gathered}
$$

$$
\begin{aligned}
& E_{t}(\text { leg })=E_{t}(\text { VOS }) * S(\text { leg }) \\
& G_{t}(\text { leg })=G_{t}(\text { VOS }) * S(l e g)
\end{aligned}
$$

where:

$\mathrm{S}(\mathrm{leg})$ is a factor used for calculating the share of energy and emissions (VOS), which is assigned to the transport service for a specific section. This share is based on relevant relations of transport activities for a section and the related VOS,

- $\quad T($ leg) is a transport service of transport activities for a given section;

- $\quad$ T(VOS) is a transport performance VOS for the section;

- $\quad \mathrm{T}(\mathrm{leg})$ and T(VOS) must have the same assignment of parameters and units.

Compared to former declaration of greenhouse gases emissions, the methodology brings the following:

- Unification of calculation methods with the application of the individual values of emission and energy factors

- Conversion to the CO2e unit, where there are direct and indirect emissions and energy consumption of the vehicle operation taken into account.

Emission factors of individual fuels are given in Table 2.

\subsection{Calculation of energy consumption and greenhouse gases emissions}

The calculation is based on real fuel consumption for the vehicles used on the basis of the parameters provided, such as the vehicle consumption. For the purposes of this contribution, transport of 50 persons was chosen on the route České Budějovice - Dubrovník using air and road transport. The starting point $S_{0}$ is České Budějovice and $S_{1}$ is Dubrovník. For comparing energy consumption and emissions, the following means of transport were chosen [8]:

- Aircraft ATR42-500. The fuel is jet fuel JET A1. The consumption of the chosen means of transport is $1.36 \mathrm{l} / \mathrm{km}$. The distance between České Budějovice and Dubrovník is

\begin{tabular}{|c|c|c|c|c|c|}
\hline \multirow{3}{*}{ Fuel } & \multirow{3}{*}{$\begin{array}{r}\text { Density (d) } \\
\text { Kg/l }\end{array}$} & \multicolumn{4}{|c|}{ Energetic factor } \\
\hline & & \multicolumn{2}{|c|}{ Thank-to-wheels (et) } & \multicolumn{2}{|c|}{ Well-to-wheels (ew) } \\
\hline & & $\mathrm{MJ} / \mathrm{Kg}$ & $\mathrm{MJ} / \mathrm{I}$ & $\mathrm{MJ} / \mathrm{Kg}$ & $\mathrm{MJ} / \mathrm{I}$ \\
\hline Gasoline & 0.745 & 43.2 & 32.2 & 50.5 & 37.7 \\
\hline Ethanol & 0.794 & 26.8 & 21.3 & 65.7 & 52.1 \\
\hline Gasoline/ethanol blend 95/5 & 0.747 & 42.4 & 31.7 & 51.4 & 38.4 \\
\hline Diesel & 0.832 & 43.1 & 35.9 & 51.3 & 42.7 \\
\hline Biodiesel & 0.890 & 36.8 & 32.8 & 76,9 & 68.5 \\
\hline Diesel /biodiesel blend 95/5 & 0.835 & 42.8 & 37.5 & 52.7 & 44.0 \\
\hline Liquefied petroleum gas (LPG) & 0.550 & 46.0 & 25.3 & 51.5 & 28.3 \\
\hline Compressed natural gas (CNG) & & 45.1 & & 50.5 & \\
\hline Aviation gasoline (Av Gas) & 0.800 & 44.3 & 35.4 & 51.8 & 41.5 \\
\hline Jet gasoline (Jet B) & 0.800 & 44.3 & 35.4 & 51.8 & 41.5 \\
\hline Jet kerosene (Jet $\mathrm{A} 1$ and Jet $\mathrm{A}$ ) & 0.800 & 44.1 & 35.3 & 52.5 & 42.0 \\
\hline Heavy fuel oil (HFO) & 0.970 & 40.5 & 39.3 & 44.1 & 42.7 \\
\hline Marine diesel oil (MDO) & 0.900 & 43.0 & 38.7 & 51.2 & 46.1 \\
\hline Marine gas oil (MGO) & 0.890 & 43 & 38.3 & 51.2 & 45.5 \\
\hline
\end{tabular}
$758 \mathrm{~km}$ (by air). In accordance with STN EN 16258, $95 \mathrm{~km}$ are added to air transport. This alternative must include journey from the town to the airport and from the airport to the point of destination.

- Bus Mercedes Benz Tourismo 0350, fuel is diesel with 6\%

Table 1 Density and energetic factor for fuels

Source: authors according to [6]. 
Table 2 Factor of fuel greenhouse gases emissions

\begin{tabular}{|c|c|c|c|c|c|c|}
\hline \multirow{3}{*}{ Fuel } & \multicolumn{6}{|c|}{ Factor of greenhouse gases emissions } \\
\hline & \multicolumn{3}{|c|}{ Thank-to-wheels (gt) } & \multicolumn{3}{|c|}{ Well-to-wheels (gw) } \\
\hline & $\mathrm{gCO}_{2} \mathrm{e} / \mathrm{MJ}$ & $\mathrm{kgCO}_{2} \mathrm{e} / \mathrm{kg}$ & $\mathrm{kgCO}_{2} \mathrm{e} / \mathrm{l}$ & $\mathrm{gCO}_{2} \mathrm{e} / \mathrm{MJ}$ & $\mathrm{kgCO}_{2} \mathrm{e} / \mathrm{kg}$ & $\mathrm{kgCO}_{2} \mathrm{e} / \mathrm{l}$ \\
\hline Gasoline & 75.2 & 3.25 & 2.42 & 89.4 & 3.86 & 2.88 \\
\hline Ethanol & 0 & 0 & 0 & 58.1 & 1.56 & 1.24 \\
\hline Gasoline / ethanol blend 95/5 & 72.6 & 3,08 & 2.30 & 88.4 & 3.74 & 2.80 \\
\hline Diesel & 74.5 & 3.21 & 2.67 & 90.4 & 3.90 & 3.24 \\
\hline Biodiesel & 0 & 0 & 0 & 58.8 & 2.16 & 1.92 \\
\hline Diesel / biodiesel blend95/5 & 71.0 & 3.04 & 2.54 & 88.8 & 3.80 & 3.17 \\
\hline Liquefied petroleum gas (LPG) & 67.3 & 3.10 & 1.70 & 75.3 & 3.46 & 1.90 \\
\hline Compressed natural gas (CNG) & 59.4 & 2.68 & & 68.1 & 3,07 & \\
\hline Aviation gas (Av Gas) & 70,6 & 3.13 & 2.50 & 84.8 & 3.76 & 3.01 \\
\hline Jet gasoline (Jet B) & 70,6 & 3.13 & 2.50 & 84.8 & 3.76 & 3.01 \\
\hline Jet kerosene (Jet A1 and Jet A) & 72.1 & 3.18 & 2.54 & 88,0 & 3.88 & 3.10 \\
\hline Heavy fuel oil (HFO) & 77.7 & 3.15 & 3.05 & 84.3 & 3.41 & 3.31 \\
\hline Marine diesel oil (MDO) & 75.3 & 3.24 & 2.92 & 91.2 & 3.92 & 3.53 \\
\hline Marine gas oil (MGO) & 75.3 & 3.24 & 2.88 & 91.2 & 3.92 & 3.49 \\
\hline
\end{tabular}

Source: authors according to [6].

share of biodiesel. Its consumption is $0.27 \mathrm{l} / \mathrm{km}$. The distance between České Budějovice and Dubrovník is1078km.

\subsection{Calculation for air transport}

The whole process of air transport consists of several sections. Passengers will be transported from S0 to the airport (S1) by bus type Karosa B931 with a diesel consumption of $0.31 / \mathrm{km}$. The length of the route is $5.1 \mathrm{~km}$. The fuel is diesel with a $6 \%$ share of biodiesel. The bus will return without passengers, but in the calculation this journey will be considered too. From S1 the passengers will fly by the ATR to Croatia (S2). From the Croatian airport, the passengers will be transported by bus IVECO, the route from the airport to the point of destination is (S3). The bus consumption is $0.2971 \mathrm{I} / \mathrm{km}$. The length of the route from the airport is $22.2 \mathrm{~km}$. The whole transportation chain is showed in Figure 2 [9], [10].

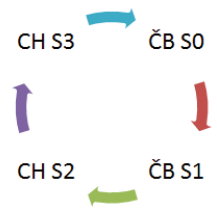

Source: authors

Figure 2 Transportation chain within calculation

\section{Calculation S0-S1 (Starting point ČB - České Budějovice airport)}

- well-to-wheels energy consumption Ew - The total energy consumption for transportation is calculated as follows: (1):

$$
E_{w}(\text { VOS })=F(\text { VOS })^{*} e_{w} \quad 1.53^{*} 42.7=65.331 \mathrm{MJ}
$$

- Calculation of tank-to-wheels energy consumption Et as follows (3):

$$
E_{t}(\text { VOS })=F(\text { VOS }) * e_{t} \quad 1.53 * 35,9=54,927 \mathrm{MJ}
$$

- Calculation of well-to-wheels greenhouse gases emissions $\mathrm{Gw}$ - The overall generation of CO2e in transportation is calculated as follows (2):

$$
G_{w}(V O S)=F(V O S)^{*} g_{w} \quad 1.53 * 3.24=4,957 \mathrm{KgCO}_{2} \mathrm{e}
$$

- Calculation of tank-to-wheels greenhouse gases emissions $\mathrm{Gt}$ - The generation of $\mathrm{CO}_{2} \mathrm{e}$ in transportation is calculated as follows (4):
$G_{t}(V O S)=F(V O S) * g_{t}$

$1.53 * 2,67=4,085 \mathrm{KgCO} \_2 \mathrm{e}$

Since it is a service where the journey back will be an empty run, it must be also included in the calculation.

$S($ leg $)=T($ leg $) / T($ VOS $) \quad=1$

$E_{w}($ leg $)=E_{w}($ VOS $) * S(l e g) \quad 65.331 * 1=65.331 \mathrm{MJ}$

Et $($ leg $)=E_{t}($ VOS $) * S(l e g) \quad 54,927 * 1=54,927 \mathrm{MJ}$

$G_{w}($ leg $)=G_{w}($ VOS $) * S($ leg $) \quad 4,957^{*} 1=4,957 \mathrm{KgCO}_{2} \mathrm{e}$

$G_{t}($ leg $)=G_{t}(V O S) * S(l e g) \quad 4,085 * 1=4,085 \mathrm{KgCO}_{2} \mathrm{e}$

Calculation of S1-S2 (ČB airport - Croatia airport)

- well-to-wheels energy consumption Ew - The overall energy consumption in transportation is calculated as follows (1):
$E_{w}(V O S)=F(V O S)^{*} e_{w}$
$1160,08 * 42=48723,36 \mathrm{MJ}$

- Calculation of tank-to-wheels energy consumption Et is calculated as follows (3):

$E_{t}($ VOS $)=F(\text { VOS })^{*} e_{t} \quad 1160,08 * 36.5=42342.92 \mathrm{MJ}$

- Calculation of well-to-wheels greenhouse gases emissions $\mathrm{Gw}$ - The overall generation of $\mathrm{CO}^{2} \mathrm{e}$ in transportation is calculated as follows (2):

$G_{w}(V O S)=F(V O S)^{*} g_{w} \quad 1160,08 * 3.10=3596.248 \mathrm{KgCO}_{2} \mathrm{e}$

- Calculation of tank-to-wheels greenhouse gases emissions $\mathrm{Gt}$ - The generation of CO2e in transportation is calculated as follows (4):

$G_{t}($ VOS $)=F($ VOS $) * g_{t} \quad 1160,08 * 2.54=2946,603 \mathrm{KgCO}_{2} \mathrm{e}$

\section{Calculation of S2-S3 (Croatia airport - point of destination}

\section{Croatia)}

well-to-wheels energy consumption Ew - The overall energy consumption in transportation is calculated as follows (1):
$E_{w}(V O S)=F(V O S)^{*} e_{w}$
$6.596 * 42.7=281,649 \mathrm{MJ}$

- Calculation of tank-to-wheels energy consumption Et is calculated as follows (3):

\section{$E_{t}($ VOS $)=F(\text { VOS })^{*} e_{t} \quad 6.596^{*} 35.9=236.796 \mathrm{MJ}$}

Calculation of well-to-wheels greenhouse gases emissions $\mathrm{Gw}$ - The overall generation of CO2e in transportation is calculated as follows (2):

$G_{w}($ VOS $)=F(\text { VOS })^{*} g_{w} \quad 6.596 * 3.24=21.371 \mathrm{KgCO}_{2} \mathrm{e}$

- Calculation of tank-to-wheels greenhouse gases emissions $\mathrm{Gt}$ - The generation of $\mathrm{CO}_{2}$ e in transportation is calculated 
as follows (4):

$G_{t}($ VOS $)=F(\text { VOS })^{*} g_{t} \quad 6.596 * 2,67=17.611 \mathrm{KgCO}_{2} \mathrm{e}$

Since it is a service where the journey back will be an empty run, it must be also included in the calculation.

$$
\begin{array}{ll}
S(\text { leg })=T(\text { leg }) / T(V O S) & =1 \\
E_{w}(\text { leg })=E_{w}(\text { VOS }) * S(l e g) & 281.649 * 1=281.649 \mathrm{MJ} \\
E t(\text { leg })=E_{t}(\text { VOS }) * S(l e g) & 236.796^{*} 1=236.796 \mathrm{MJ} \\
G_{w}(\text { leg })=G_{w}(\text { VOS }) * S(l e g) & 21.371 * 1=21.371 \mathrm{KgCO}_{2} \mathrm{e} \\
G_{t}(\text { leg })=G_{t}(\text { VOS }) * S(\text { leg }) & 17.611^{*} 1=17.611 \mathrm{KgCO}_{2} \mathrm{e}
\end{array}
$$

The whole transportation process is thus completed and the resulting values have to be added up.

Table 3 Resulting values for air transport calculation

\begin{tabular}{|l|l|}
\hline The results for air transport & $49070.34 \mathrm{MJ}$ \\
\hline well-to-wheels energy consumption Ew & $42634.643 \mathrm{MJ}$ \\
\hline tank-to-wheels energy consumption Et & 3622.576 \\
\hline well-to-wheels greenhouse gases emissions Gw & 2968.299 \\
\hline tank-to-wheels greenhouse gases emissions Gt &
\end{tabular}

Source: authors

\subsection{Calculation for road transport}

Since the chosen fuel is diesel with a $6 \%$ share of biodiesel, the calculations shall be based on energy and emission factors of diesel / biodiesel, not only on the factors given in Table 1 and 2 as in the case of air transport. The parameters of diesel / biodiesel are annexed in STN EN 16258 (2013).

- well-to-wheels energy consumption Ew - The overall energy consumption in transportation is calculated as follows (1):
$E_{w}(V O S)=F(V O S)^{*} e_{w}$
$291,06 * 42.2=12282.732 \mathrm{MJ}$

- Calculation of tank-to-wheels energy consumption Et is calculated as follows (3):

$$
E_{t}(\text { VOS })=F(\text { VOS })^{*} e_{t} \quad 291.06 * 35.7=10390.842 \mathrm{MJ}
$$

- Calculation of well-to-wheels greenhouse gases emissions $\mathrm{Gw}$ - The overall generation of $\mathrm{CO} 2 \mathrm{e}$ in transportation is calculated as follows (2):

$$
G_{w}(\text { VOS })=F(\text { VOS })^{*} g_{w} \quad 291.06 * 2.51=730.561 \mathrm{KgCO}_{2} e
$$

- Calculation of tank-to-wheels greenhouse gases emissions $\mathrm{Gt}$ - The generation of $\mathrm{CO} 2 \mathrm{e}$ in transportation is calculated as follows (4):

$$
G_{t}(\text { VOS })=F(\text { VOS })^{*} g_{t} \quad 291.06 * 3.16=919.750 \mathrm{KgCO}_{2} e
$$

Table 4. Resulting values for road transport calculation

\section{Results for road transport}

well-to-wheels energy consumption Ew

$12282.732 \mathrm{MJ}$

tank-to-wheels energy consumption Et $10390.842 \mathrm{MJ}$

well-to-wheels greenhouse gases emissions $\mathrm{Gw}$

730.561

tank-to-wheels greenhouse gases emissions Gt 919.750

Source: authors

\section{Research results}

According to EN 16258 (2013), which deals with the calculation and declaration of energy consumption and greenhouse gases emissions of transport services, the values of energy intensity and generation of greenhouse gases on the selected route. The results for road and air transport obtained were subsequently compared. The selected route was the route České Budějovice (Czech Republic) - Dubrovnik (Croatia). The results of both alternatives are showed in Table 5.

The resulting values are a basis for declaration of energy consumption and greenhouse gases emissions. This declaration contains all the four results demanded in accordance with EN 16256 (2013) [11], [12]:

- Well-to-wheels greenhouse gases emissions of transport service $\mathrm{Gw}$.

- Tank-to-wheels greenhouse gases emissions of transport service Gt.

- Well-to-wheels energy consumption of transport service Ew.

- Tank-to-wheels energy consumption of transport service Et.

This example illustrates the methodology and the application of the standard for calculations in road freight transport and is the key for creating valid software to be used for calculation of energy consumption and emission generation from the primary transport service.

\section{CONCLUSION}

In this contribution, the calculation of energy consumption and greenhouse gases generation on the selected route was carried out. It is possible to apply this model to individual types of fuel and thus compare energy intensity of individual types of fuel. Since currently the environment is mainly influenced in a negative way, it is important to be aware of this negative impact. The research has shown that in this model case, the values calculated for air transported were higher than for the road transport. However, the global view must be taken into account. Compared to other modes of transport in the Czech Republic, road transport is still the number one polluter of the environment. It refers especially to individual passenger transport and freight transport. Road transport is followed by air transport, rail and water transport. In a global perspective, it is always necessary to focus on the overall share of the individual modes of transport on transport market. Taking into account the number of passengers transported and the number of vehicles, it is more efficient to convert the energy intensity and greenhouse gases emissions per person. Table 3 shows the data of energy consumption and greenhouse gases emissions for aircraft ATR 42/500 and bus Mercedes Benz

Table 5 Comparison of individual results

\begin{tabular}{|l|l|l|}
\hline & Air transport & Road transport \\
\hline well-to-wheels energy consumption Ew & $49070.34 \mathrm{MJ}$ & $12282.732 \mathrm{MJ}$ \\
\hline tank-to-wheels energy consumption Et & $42634.643 \mathrm{MJ}$ & $10390.842 \mathrm{MJ}$ \\
\hline well-to-wheels greenhouse gases emissions Gw & 3622.576 & 730.561 \\
\hline tank-to-wheels greenhouse gases emissions Gt & 2968.299 & 919.750 \\
\hline
\end{tabular}

Source: authors 
O350, and it must be emphasized that the methodology deals with the calculation of greenhouse gases emissions within a specific transportation, where the authors compared the transport of 50 passengers by air and road transport.

\section{Acknowledgement}

This contribution was created within the solution of the Czech research project LTC17040 named "Regionální letiště v České a Slovenské republice a vliv jejich provozu na ekonomický rozvoj regionu" of the INTER-EXCELLENCE program, the INTER-COST subprogram.

\section{REFERENCES}

[1] Hao, H., Liu, F.Q., Liu, Z.W., Zhao, F.Q., Compression ignition of low-octane gasoline: Life cycle energy consumption and greenhouse gas emissions. Applied Energy, 2016, Vol. 181, pp. 391-398. https://doi.org/10.1016/j. apenergy.2016.08.100

[2] Becker, U., Gerike, R., Winter, M. Základy dopravní ekologie. Prague: Ústav pro ekopolitiku, Czech Republic, 2008. ISBN 978-80-87099-05-6.

[3] Schmied, M., Knörr, W. Calculating GHG emissions for freight forwarding and logistics services in accordance with EN 1625.: European Association for Forwarding, Transport, Logistics and Customs Services (CLECAT), April 2012.

[4] Ližbetin, J., Stopka, O., Němec, F. Methodological Assessment of Environmental Indicators in Combined Transport in Comparison with Direct Road Freight
Transport. In: Transport Means 2016. Kaunas, Lithuania: Kaunas University of technology press, 2016, pp. 151-155. ISSN 1822-296X.

[5] Telang, S. How to calculate carbon dioxide equivalent emissions from different GHG sources? http://greencleanguide.com/. [online], 2012, Available on: http://greencleanguide.com/2012/06/05/how-to-calculate-carbon-dioxideequivalent-emissions-from-different-ghg-sources/

[6] EN16258. 2013: CEN, 2013. Methodology for calculation and declaration of energy consumption and GHG emissions.

[7] Hromádko, J. Speciální spalovací motory a alternativní pohony. Praha: Grada Publishing, a.s., 2012. ISBN 978-80-247-4455-1.

[8] Ližbetin, J., Kampf, R., Jeřábek, K., Caha, Z. Practical Application of the Comparative Analysis of Direct Road Freight Transport and Combined Transport. In: Transport Means 2016. Kaunas, Lithuania: Kaunas University of Technology Press, 2016. pp. 1083-1087. ISSN 1822-296X

[9] Kuptcova, A., Prusa, P., Fedorko, G., et al. Data mining workspace as an optimization prediction technique for solving transport problems. Transport Problems, 2016, Vol.11, No. 3, pp. 21-31. https://doi.org/10.20858/ tp.2016.11.3.3

[10] Sułek, J., Filina-Dawidowicz, L. Water-bus in the public transport. Scientific Journals of the Maritime University of Szczecin, 2014, Vol. 37, No. 109, pp. 8288. ISSN 1733-8670.

[11] Fedorko, G., et al. Development of simulation model for light-controlled road junction in the program Technomatix Plant Simulation. Transp. Means, 2015, pp. 466-469.

[12] Keskisaari, V., Ottelin, J., Heinonen, J. Greenhouse gas impacts of different modality style classes using latent class travel behavior model. Journal of Transport Geography, 2017, Vol. 65, pp. 155-164. https://doi.org/10.1016/j. jtrangeo.2017.10.018 